\title{
Waking up from the middle-income country dream: COVID-19 and the human development crisis in Peru
}

Jhonatan Clausen ${ }^{1}$

\section{Contribución en la Sección Panorama Social}

Resumen: Este artículo analiza la crisis de desarrollo humano ocasionada en el Perú por la Covid-19 y muestra cómo el caso peruano ilustra de forma clara el desencuentro entre crecimiento económico y bienestar humano. Tomando como referencia las ideas de Amartya Sen, el artículo plantea una serie de preguntas de investigación que la literatura de las ciencias sociales en el Perú ha de enfrentar en el futuro cercano. Este conjunto preguntas de investigación llevan al enfoque de desarrollo humano y capacidades a extender sus propias fronteras para profundizar en el estudio del poder y su vinculación con la capacidad del razonamiento público para albergar preocupaciones relacionadas a la erradicación de privaciones en dimensiones básicas del bienestar de las personas.

It is common for many textbooks on human development and the capability approach to start with some kind of example in which it is made clear that assessing well-being requires going 'beyond income' and that development is 'more than economic growth' (Nussbaum, 2012; Deneulin et al. 2018; Deneulin, 2014; Alkire and Deneulin, 2009). Along these lines, regardless of whether or not one agrees with this approach, the truth is that these ideas are already quite established in the field of development studies and in current international development narratives, such as the Sustainable Development Goals (SDG) (United Nations [UN], 2015).

Although the normative discourse that underlies the human development and capability approach seems to have permeated development narratives in Latin America, in many countries in this region, there is still a gap between what is 'known' about development and what is 'done' about it. In other words, there is a mismatch between the official discourses on what is understood by development and the development policies that are actually implemented (Deneulin and Sánchez-Ancochea, 2018).

The health crisis caused by COVID-19 has starkly exposed this gap. Currently, Latin America is one of the regions in the world that have been the most affected by the health

\footnotetext{
${ }^{1}$ Department of Economics of the Pontifical Catholic University of Peru (PUCP) and Human Development Institute in Latin America (IDHAL) at PUCP. Correo electrónico: jhonatan.clausen@pucp.edu.pe
} 
crisis, which threatens to lead to an economic, food, and humanitarian crisis (Food and Agriculture Organization [FAO], 2020). Among the countries in this region, the case of Peru stands out because by the beginning of September, the country had the world's highest COVID-19 mortality rate (World Health Organization [WHO], 2020).

In 2008, Peru joined the group of middle-income countries (Vostroknutova et al. 2015). A few years later, at the beginning of 2020, Peru came to be considered a 'star' in Latin America due to its good macroeconomic performance (International Monetary Fund [IMF], 2020), which made it one of the few countries in the region with a GDP that continued to grow despite the global economic slowdown (IMF, 2020). These results led The Economist (2020) to rate Peru as the fourth strongest economy out of 66 emerging economies worldwide. Six months later, Peru was the country with the highest COVID-19 mortality rate in the world. How did Peru go from being the 'star' of Latin America to experiencing the worst human development crisis in practically all of its republican history in just 6 months?

Peru was one of the first countries in Latin America to close its borders and impose a strict quarantine at the national level, which began in mid-March. However, the country's macroeconomic strength at the beginning of the pandemic contrasted with the severe weakness of the health system (less than a thousand intensive care units throughout the country, (Superintendencia Nacional de Salud [SUSALUD], 2020), high rates of labour informality $-72.6 \%$ (Instituto Nacional de Estadistica e Informatica [INEI], 2019)- and a significant percentage of people $-30 \%$, (Clausen, 2020)- for whom a series of deprivations were concentrated, placing them in a situation of particular vulnerability to COVID-19 (such as a lack of water, poor sanitation, the use of polluting fuels for cooking, overcrowding, lack of access to a refrigerator, and the presence of people with chronic diseases in the household). Likewise, a national survey carried out by the Institute of Peruvian Studies (IEP) in May this year has already indicated the early effects of the pandemic: $60 \%$ of people were more afraid of hunger than COVID-19, 30\% had lost their job, $61 \%$ had stopped paying for at least one public service (such as water, electricity, or telephone service), and $74 \%$ said they had suffered from anguish or anxiety (IEP, 2020).

The feeling of 'astonishment' regarding the generalised precariousness that the pandemic helped to make visible in the Peruvian media contrasts with the intentions that Peru had, until a few months ago, to join the Organisation for Economic Cooperation and Development (OECD, 2019) club of rich countries, like Chile and Colombia. This revelation would later give way to the recognition that, despite the economic boom, Peru had 'forgotten' to invest in education and health (El Comercio, 2020) and that Peru could not 'be among the first in macroeconomics whilst being the last in the quality of public services' (Alva, 2020). Months later, in September, Peru would join the health and economic crisis, a political crisis 
caused by an attempted impeachment led by the Peruvian congress based on alleged acts of presidential corruption.

How can a country simply 'forget' to allocate resources to two central dimensions of human development, such as health and education? How can macroeconomic strength coexist with generalised precariousness and institutional fragility? These questions arise as central topics of a research agenda that Peruvian social scientists have not yet been able to answer satisfactorily.

The work of Amartya Sen, initiator of the so-called capability approach, may be useful to begin the process of answering some of the abovementioned questions. In his conference Poverty and the Tolerance of the Intolerable (2014), Sen discusses some of the ideas proposed in a book he co-wrote with Jean Drèze, titled An Uncertain Glory: India and Its Contradictions (2013), which addresses how Indian society can tolerate the existence of extreme deprivations, precisely in the midst of accelerated economic growth processes.

In the conference, Sen proposes three possible reasons for a society to effectively be capable of tolerating the intolerable: i) society is not aware of the existence of these deprivations (hypothesis of ignorance), ii) society is aware of these deprivations but considers poverty to be 'something inevitable' that 'has always been there', and iii) people are focused on themselves and do not really care about the deprivations that others may experience. However, in Sen's opinion, none of the three explanations is satisfactory, and he concludes that the tolerance of the intolerable corresponds, in reality, to a 'failure of public reasoning' (Sen, 2014).

Can Sen's ideas tell us something about the 'forgetfulness' of the Peruvian society in relation to the importance of human development beyond economic growth? Following in the steps of Deneulin and Clausen (2019), who applied Sen's ideas in Collective Choice and Social Welfare (2017) to Peru's reality, it is possible to outline some hypotheses in order to determine to what extent the current situation in Peru can effectively be explained as a 'failure' of public reasoning or as 'poor' public deliberation.

A point in the aforementioned direction may correspond to refining the question and clearly determining who is responsible for this 'forgetfulness'. Is it really possible to speak of something like this as social 'forgetting'? Is it perhaps 'forgetfulness' on the part of the political class or the economic power elites? In their article, Deneulin and Clausen (2019) offer evidence that the permanence of the goal of eradicating severe deprivations and vulnerabilities within Peru's public agenda is very fragile. It would, therefore, be a situation of the 'vulnerability of the vulnerability'. However, those responsible and the causes behind this phenomenon need to be further explored. 
Responding to the questions that the human development crisis in Peru raises may imply the need to explore new frontiers of the human development and capability approach itself. Along these lines, the approach must be able to delve into the exhaustive analysis of power structures from the conceptual point of view, but specially from the empirical point of view. Although the study of structures has already been proposed in the literature on the approach (Deneulin et al. 2006), it remains relatively underexplored (Patrón, 2019), especially from the applied literature point of view. How can the 'quality' of public reasoning be evaluated? What information is required to account for the failures in this area? To what extent is this reasoning representative of society? These are urgent questions to be discussed, not only in the Peruvian case, but throughout Latin America in general.

The Peruvian case described in this brief article may also trigger a process of selfcriticism for academics related to the human development and capability approach and, in general, social scientists involved in development studies in Peru. Is it that obvious that development is more than economic growth and that well-being is more than income? How successful have we been in clearly communicating to a broad audience the implications of a taking normative language, like the one proposed by the human development and capability approach, seriously? If part of the precarious situation exposed by the COVID-19 crisis was already identified and documented, why were our books, articles, and conferences unable to 'inform' or 'improve' the public reasoning to wake us from the dream of the fragile discourse of middle-income Peru?

References to the term 'new normal' have become ubiquitous more than 6 months after the start of the COVID-19 pandemic in Latin America. However, the path that this 'new normal' will follow remains uncertain. The human development and capability approach provides powerful tools to avoid the 'novelty' of the post pandemic normality resulting in higher levels of deprivation and inequalities than those already faced by a large portion of the countries in the region. However, for this to occur, it will be necessary to take the approach to its limits and, above all, build bridges between the generation of rigorous knowledge and the generation of truly transformative actions.

\section{References}

Alkire, S. and Deneulin, S. (2009). A Normative Framework for Development. In S. Deneulin and L. Shahani (Eds), An Introduction to the Human Development and Capability Approach: Freedom and Agency (pp. 3-21). United Kingdom: Earthscan.

Alva, M. A. (2020, May 17). María Antonieta Alva: "El Perú no puede estar entre los primeros en macroeconomía y los últimos en calidad de los servicios públicos". 
La República. Retrieved from https://larepublica.pe/politica/2020/05/17/mariaantonieta-alva-el-peru-no-puede-estar-entre-primeros-en-macroeconomia-yultimos-en-calidad-de-servicios-mef/

Clausen, J. (2020, April 19). COVID-19 y Pobreza multidimensional en el Perú [Blog]. Retrieved from http://blog.pucp.edu.pe/blog/idhal/2020/04/19/COVID-19-ypobreza-multidimensional-en-el-peru/

Deneulin, S., Nevel, N., and Sagovsky, N. (Eds). (2006). Transforming Unjust Structures: The Capability Approach. Netherlands: Springer.

Deneulin, S. (2014). Wellbeing, Justice and Development Ethics. United Kingdom: Routledge.

Deneulin, S., Clausen, J. and Valencia, A. (Eds). (2018). Introducción al enfoque de las capacidades: Aportes para el Desarrollo Humano en América Latina. Argentina: Manantial.

Deneulin, S. and Sánchez-Ancochea, D. (2018). Urban inequality, youth and social policy in Latin America: introduction to special section. Oxford Development Studies, 46(1), 3-9.

Deneulin, S. and Clausen, J. (2019). Collective Choice and Social Welfare by Amartya Sen: A review essay with reference to development in Peru. Development Policy Review, 37(4), 564- 578.

https://doi-org.ezproxybib.pucp.edu.pe/10.1111/dpr.12376

Drèze, J. and Sen, A. (2013). An Uncertain Glory: India and its Contradictions. Princeton; Oxford: Princeton University Press. doi:10.2307/j.ctt32bcbm

El Comercio (2020, April 30). Enfrentando el COVID-19: ¿qué carencias tiene el Perú frente a otros países de la región? Retrieved from https://elcomercio.pe/economia/peru/coronavirus-peru-enfrentando-el-COVID19-que-carencias-tiene-el-peru-frente-a-otros-paises-de-la-region-medicosgasto-corriente-en-salud-conectividad-noticia/

Food and Agriculture Organization (2020). Impacto del COVID-19 en la pobreza: Pobreza inducida en América y el Caribe producto del COVID-19. Santiago. https://doi.org/10.4060/ca9272es

Institute of Peruvian Studies (2020). Desigualdad, vulnerabilidades y estrategias frente al COVID-19. Encuesta telefónica a nivel nacional. Retrieved from: https://iep.org.pe/wp-content/uploads/2020/06/IEP.-Desigualdadvulnerabilidades-y-estrategias-en-la-crisis-del-COVID-19-mayo-2020.pdf 
International Monetary Fund. (2020). IMF Country Report No. 20/3. Washington, D.C.: International Monetary Fund.

Instituto Nacional de Estadistica e Informatica. (2019). Encuesta Nacional de Hogares sobre Condiciones de Vida y Pobreza.

Nussbaum, M. (2012). Crear capacidades. Madrid: Paidós.

Organisation for Economic Cooperation and Development. (2019). Peru's path to a highincome economy with better well-being for all citizens. In OECD: Multidimensional Review of Peru: Volume 3. From Analysis to Action. Paris: OECD Publishing.

Patrón P. (2019). Power and Deliberative Participation in Sen's Capability Approach. In: D. Clark, M. Biggeri and A. Frediani (Eds), The Capability Approach, Empowerment and Participation (pp. 55-74). Londres: Palgrave Macmillan. https://doi.org/10.1057/978-1-137-35230-9_3

Sen, A. (2014, January 22). Poverty: The Tolerance of the Intolerable. United Kingdom: London School of Economics.

Sen, A. (2017). Collective Choice and Social Welfare: An Expanded Edition. United States: Harvard University Press.

Superintendencia Nacional de Salud (2020). Seguimiento del registro de camas F500.2, aplicativo para gestión centralizada de la disponibilidad de camas de hospitalización y $\mathrm{UCl}$ a nivel nacional y de todos los subsistemas. Available online: http://portal.susalud.gob.pe/seguimiento-del-registro-de-camas-f500-2/

The Economist (2020, May 29). Next in line: Which emerging markets are in most financial peril? https://www.economist.com/briefing/2020/05/02/which-emerging-marketsare-in-most-financial-peril

United Nations (2015). Transforming our world: The 2030 agenda for sustainable development. Retrieved from https://sustainabledevelopment.un.org/content/documents/21252030\%20Agenda \%20for\%20Sustainable\%20Development\%20web.pdf

Vostroknutova, E., Rodriguez, A., Saavedra, P. and Panzer, J. (2015). Peru - Building on success: boosting productivity for faster growth. Washington, D.C.: World Bank Group.

World Health Organization (2020). WHO COVID-19 Explorer. Geneva: World Health Organization, 2020. Available online: https://covid19.who.int/ 